\title{
Evaluation of tissue reaction to Aroeira (Myracrodruon urundeuva) extracts: a histologic and edemogenic study
}

\author{
Alessandra Cury MACHADO' ${ }^{1}$, Eloi DEZAN JUNIOR², João Eduardo GOMES-FILHO², Luciano Tavares Angelo CINTRA², \\ Denise Belucio RUVIÉRE ${ }^{4}$, Renata ZOCCAL ${ }^{5}$, Carla Andreotti DAMANTE ${ }^{6}$, Elerson GAETTI JARDIM JUNIOR ${ }^{7}$

\footnotetext{
1- DDS, MS, Graduate student, Department of Pediatrics, Araçatuba School of Dentistry, UNESP - Univ. Estadual Paulista, Araçatuba, SP, Brazil.

2- DDS, PhD, Associate Professor, Department of Endodontics, Araçatuba School of Dentistry, UNESP - Univ. Estadual Paulista, Araçatuba, SP, Brazil.

3- DDS, PhD, Assistant Professor, Department of Endodontics, Araçatuba School of Dentistry, UNESP - Univ. Estadual Paulista, Araçatuba, SP, Brazil.

4- DDS, PhD, Graduate student, Department of Pediatrics, Araçatuba School of Dentistry, UNESP - Univ. Estadual Paulista, Araçatuba, SP, Brazil.

5- DDS, MS, Graduate student, Department of Pediatrics, Araçatuba School of Dentistry, UNESP - Univ. Estadual Paulista, Araçatuba, SP, Brazil.

6- DDS, PhD, Assistant Professor, Department of Periodontology, Bauru School of Dentistry, University of São Paulo, Bauru, SP, Brazil.

7- DDS, PhD, Associate Professor, Department of Microbiology, Araçatuba School of Dentistry, UNESP - Univ. Estadual Paulista, Araçatuba, SP, Brazil.
}

Corresponding address: Eloi Dezan Junior - Rua José Bonifácio, 1193 - Araçatuba - SP - Brasil - 16.015-050 - Phone: 551836363254 - e-mail: dezan@ foa.unesp.br

Received: September 29, 2010 - Modification: October 8, 2011 - Accepted: October 24, 2011

\section{ABSTRACT}

\begin{abstract}
O bjectives: This study evaluated subcutaneous tissue response to Aroeira (Myracrodruon urundeuva) extract employing edemogenic and histological analyses. Material and methods: Test groups consisted of aqueous and ethanolic Aroeira extracts and saline (control). For edema quantification, 18 rats received an intravenous injection of Evan's Blue. After $30 \mathrm{~min}$, the extracts and saline were injected on the dorsum of the rats, which were then sacrificed after 3 and $6 \mathrm{~h}$. Readings were performed in a spectrophotometer. For subcutaneous implantation, 30 rats received a polyethylene tube containing the extracts on their dorsum and then they were killed after 7 and 28 days. The samples were processed for histological analysis and evaluated with a light microscope. The inflammatory infiltrate was quantified. Results: There were no statistically significant differences between aqueous extract and saline groups in relation to edema quantification in the different periods $(p>0.05)$. Ethanolic solution resulted in more edema independently of the experimental period $(p<0.05)$. Histological analysis showed similar results on the 7 -day period for the 3 groups. There was a notable reduction on inflammatory cell number for saline and aqueous extract groups at 28 days. Conclusion: The aqueous extract showed biocompatible properties similar to those of saline.
\end{abstract}

Key words: Inflammation. Edema. Medicinal plants. Anacardiaceae.

\section{INTRODUCTION}

Studies on medicinal plants date from the past century, but their use is as ancient as humanity ${ }^{22}$. According to the World Health Organization (WHO), approximately 3.5 billion people in developing countries believe in the efficiency of herbal medicines and use them regularly ${ }^{4}$, and estimates that $65-80 \%$ of this population uses medicinal plants as the only way to treat health problems ${ }^{23}$.

Brazil possesses a large biodiversity and has a wealth of traditional knowledge accumulated by local people who have direct access to nature and its products. Traditional knowledge related to medicinal plants is the basis of folk medicine in Brazil, which is derived from a mixture of Brazilian indigenous cultures and European and African influences from the colonization period ${ }^{9}$.

Myracrodruon urundeuva, popularly known as "Aroeira do sertão", is a Brazilian medicinal plant traditionally used for treating gingival bleeding and gynecological disorders ${ }^{11,20}$. It is a large tree that grows in Northeastern region of Brazil. Ethanolic extracts from Myracrodruon urundeuva stem bark exert anti-inflammatory activity in several experimental models of inflammation, such as 
carrageenan-induced paw edema, neutrophil migration to peritoneal cavity and hemorrhagic cystitis induced by cyclophosphamide ${ }^{20,21}$. Analgesic, antiulcer, hepatoprotective, antidiarrheal and colonic anastomotic wound healing properties have been reported ${ }^{5,21}$. A chemical study has demonstrated that the ethyl acetate extract has two main fractions. One of them has predominance of substances of a chalcone nature and the other has predominance of catechic tannins ${ }^{21}$. The chalcone demonstrated neuroprotective effects, which are able to reduce oxidative stress and apoptotic injury ${ }^{13}$.

Few studies have addressed the toxic effects of these extracts. Almeida, et al. ${ }^{1}$ (2010) found high toxic effects in the ethanolic Aroeira extract. Based on these findings, the aim of this study was to evaluate the immediate and late biological tissue responses to ethanolic and aqueous Aroeira extracts implanted in rat submucosa.

\section{MATERIAL AND METHODS}

The study was approved by Ethics committee on animal research of Araçatuba School of Dentistry/ UNESP (Process \#2007-008938).

\section{Plant extract preparation}

The Aroeira (Myracrodruon urundeuva) plants were obtained from ecological reserves at Carolina city, Maranhão state, Brazil. The leaves were collected if presented with a healthy aspect, no signs of aging and free of disease and pests. After collection, the plants were washed in water, dried at room temperature and in a heater at $37^{\circ} \mathrm{C}$ until becoming dry and friable. Subsequently they were pulverized.

The ethanolic and aqueous extracts were prepared according to the methodology described by Tsuchiya, et al. ${ }^{18}$ (1994) and Navarro, et al. ${ }^{12}$ (1998). For the ethanolic extract, $20 \mathrm{~g}$ of leaf powder were mixed to $250 \mathrm{~mL}$ of $80 \%$ ethanol. The flask was agitated vigorously during $3 \mathrm{~min}$, five times a day, during 12 days. The solution was filtered in paper filters and sterilized by filtration in Millipore membranes $(0.22 \mu \mathrm{m})$. The aqueous extract was obtained by mixing $20 \mathrm{~g}$ of leaf powder with $250 \mathrm{~mL}$ of distilled water. The solution was maintained at $100^{\circ} \mathrm{C}$ for $5 \mathrm{~min}, 55^{\circ} \mathrm{C}$ for $1 \mathrm{~h}$ and at room temperature for $72 \mathrm{~h}$. Agitation was performed every $24 \mathrm{~h}$. The extract was filtered and sterilized as mentioned before.

\section{Edemogenic test - immediate reaction}

Eighteen 4-6 month-old male Wistar rats weighting 250-280 g were divided into 6 groups of 3 animals each according to the experimental period of analysis ( 3 and $6 \mathrm{~h}$ ) and treatment with the ethanolic/aqueous extracts or saline (control). The animals were anesthetized with xylazine (10 $\mathrm{mg} / \mathrm{kg}$ ) and ketamine $(25 \mathrm{mg} / \mathrm{kg}$ ) and received an intravenous injection of $1 \%$ Evan's blue $(0.2 \mathrm{~mL} / 100$ g body weight) (Evan's Blue; Difco Lab, Detroit, Michigan, USA). After $30 \mathrm{~min}, 0.1 \mathrm{~mL}$ of the extracts or saline were injected at the dorsum region, near the tail and using the median line as a reference.

After 3 and $6 \mathrm{~h}$, the animals were sacrificed by anesthetic overdose and a $23 \mathrm{~mm}$ of diameter tissue fragment containing a blue halo in the center was removed. The tissue was fixed in $4 \mathrm{~mL}$ of formamide for $72 \mathrm{~h}$ at $45^{\circ} \mathrm{C}$ and filtered for spectrophotometric analysis at $630 \mathrm{~nm}$.

\section{Implantation in subcutaneous tissue for histological analysis}

Thirty 4-6 month-old male Wistar albino rats weighting 250-280g were divided into six groups of 5 animals each according to the experimental period of analysis ( 7 and 28 days) and treatment with the ethanolic/aqueous extracts or saline (control).

Sixty polyethylene tubes $(1.0 \mathrm{~mm}$ internal diameter $\times 1.6 \mathrm{~mm}$ outer diameter $\times 10 \mathrm{~mm}$ length) with a paper cone inside $(2 \mathrm{~mm}$ short of the cone length) had one side filled with $1 \mathrm{~mm}$ of guttapercha, and were sterilized with nitrous oxide.

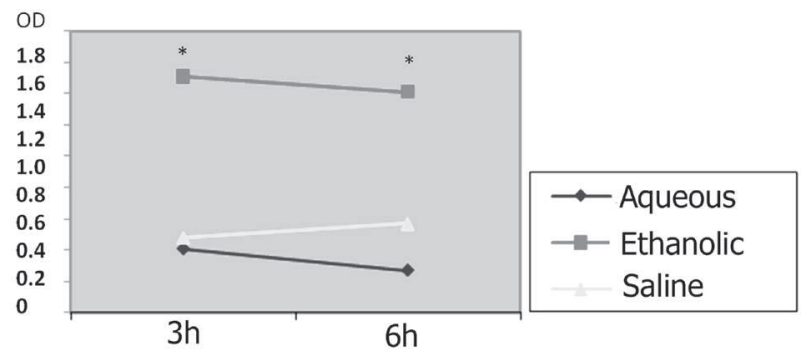

Figure 1- Mean values of edema on both time period and the experimental groups

$\mathrm{OD}=$ Optical Density $\left({ }^{*} \mathrm{P}<0.05\right)$

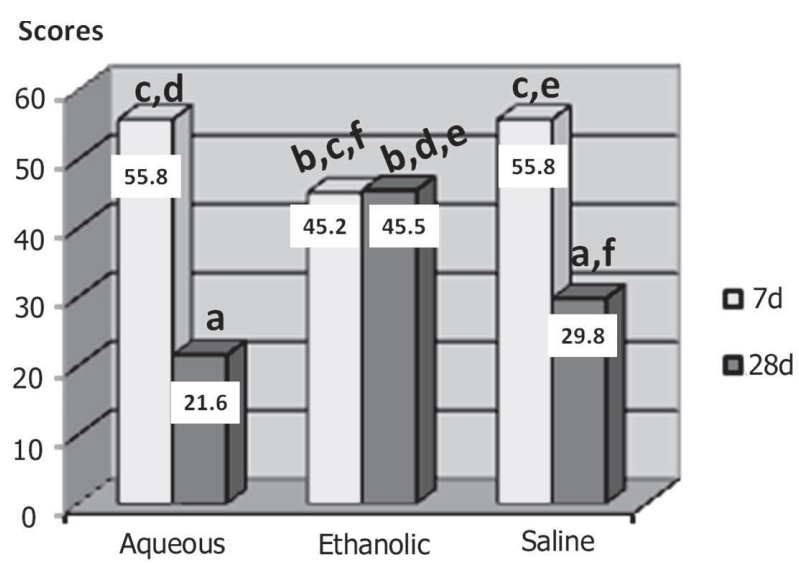

Figure 2- Mean scores of inflammatory cells of the three groups at each time period Different letters $=p<0.05$. Same letters $=p>0.05$ 


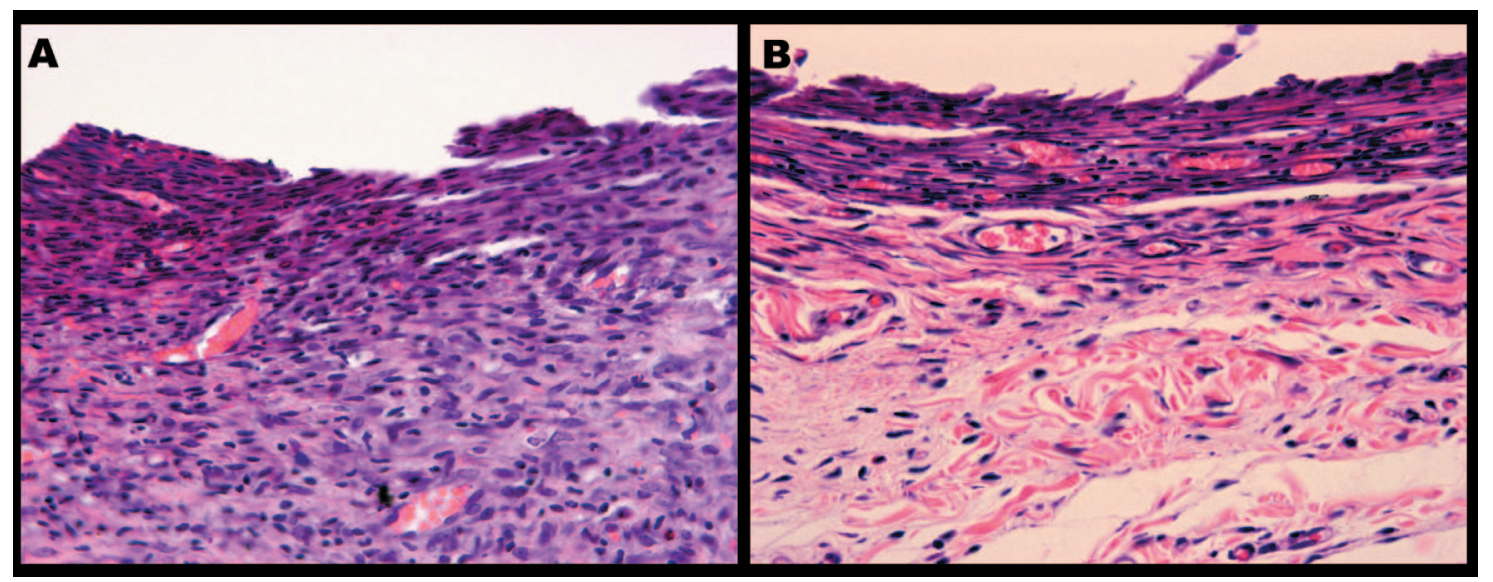

Figure 3- Control group (saline). A - At 7 days, there is an aggressive inflammatory response. The granulation tissue is thick and presents macrophages and lymphocytes. Fibroblasts are near the collagen fibers in a disorganized distribution. Blood vessels are distributed all over the tissue. B - At 28 days, the fibrous tissue present well organized collagen fibers parallel to implant. There are a few inflammatory cells and capillaries. HE - Original magnification=40x

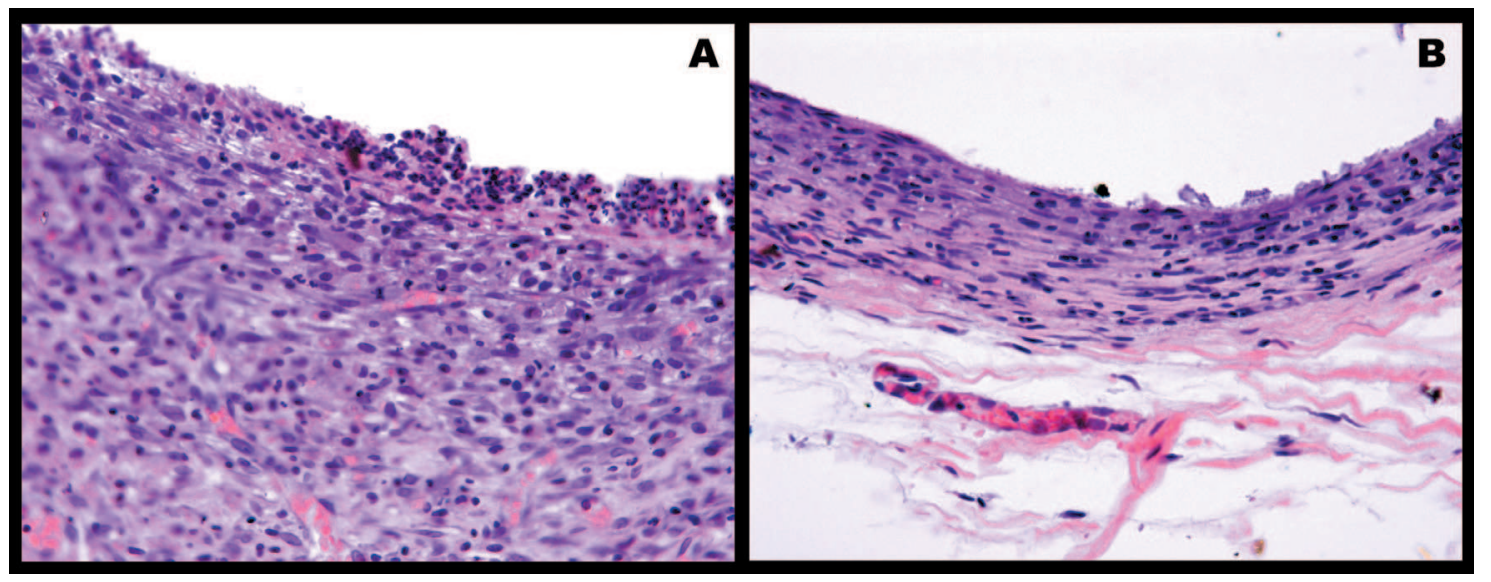

Figure 4- Aroeira's aqueous extract group. A - At 7 days, the granulation tissue is thick and presents inflammatory infiltrate with macrophages and lymphocytes. Fibroblasts appear near the collagen fibers and blood vessels are distributed all over the granulation tissue. B - At 28 days, the connective tissue shows a few fibroblasts, inflammatory cells and blood vessels. Fibroblasts are disposed in line with the collagen fibers. HE - Original magnification 40x

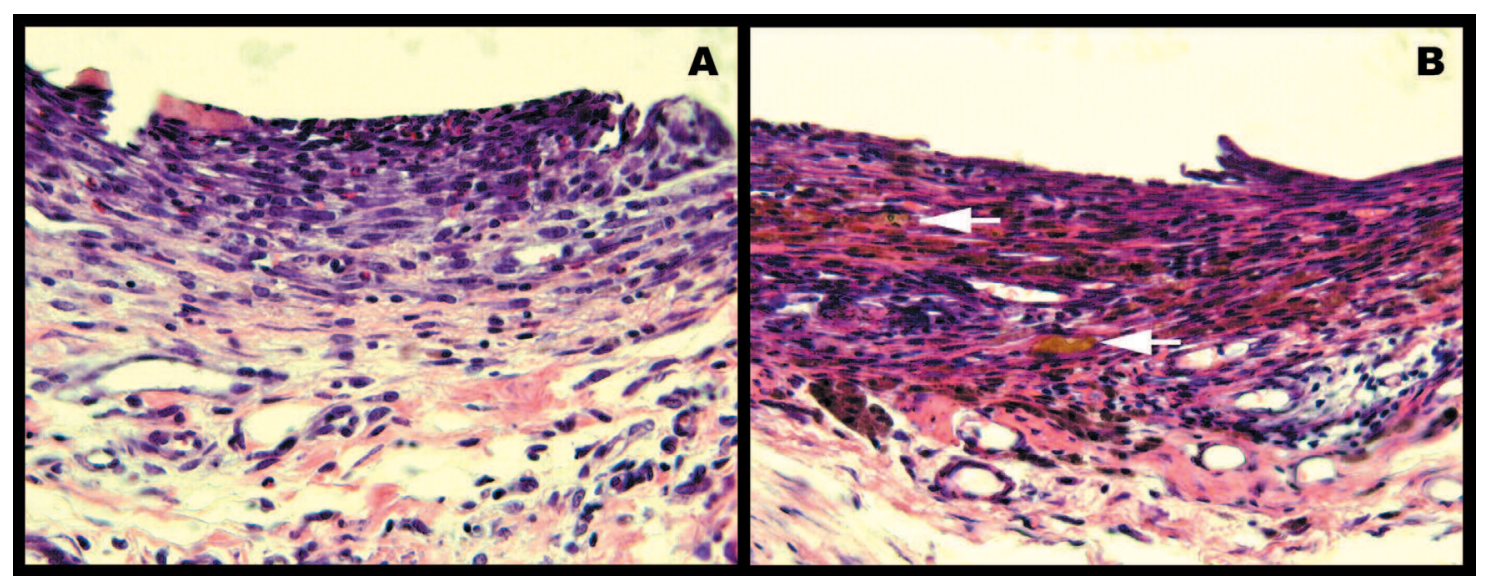

Figure 5- Aroeira's ethanolic extract group. A - At 7 days, the granulation tissue is thick and presents macrophages, lymphocytes and rare neutrophils. Blood vessels are distributed all over the tissue and the fibroblasts are near disorganized collagen fibers at the periphery of the tissue. B - At 28 days, the connective tissue is thin with rare inflammatory cells. Blood vessels are distributed along the granulation tissue. Arrows point a hemorragic area pigmented by hemossiderin. Fibroblasts are near collagen fibers at the central and periphery regions of granulation tissue. HE - Original Magnification 40x 
The animals received antisepsis with $5 \%$ iodine solution and were shaved under anesthesia. The shaved back received an incision in a head to tail orientation with a \#15 blade. The skin was reflected creating two pockets: one on the right side and the other on the left side. The tubes were implanted into the spaces created with blunt dissection and the skin closed with a 4/0 silk suture.

Each animal received 2 implants with the same solution totalizing 10 implants per experimental group. After 7 and 28 days after implantation the animals were killed by anesthetic overdose and the tubes and surrounding tissue were explanted, fixed in $10 \%$ formalin and processed and stained with hematoxylin eosin.

\section{Histological analysis}

All analyses were performed with a light microscope and original magnification of $40 x$.

The quantitative analysis of inflammation was performed according to the number of inflammatory cells present and divided in scores ${ }^{2,3}$.

Absent $=$ absence of inflammatory cells

Low $=<25$ inflammatory cells

Moderate $=25-125$ inflammatory cells

Severe $=>125$ inflammatory cells

\section{Statistical analysis}

Data from the edemogenic analysis were analyzed by two-way ANOVA and Tukey's test $(p<0.05)$. Data from the histological analysis were analyzed by the Mann-Whitney and Kruskal-Wallis tests. A significance level of $5 \%$ was set for all analyses.

\section{RESULTS}

\section{Edemogenic analysis}

The results for edema quantification showed no statistically significant differences between the experiemntal periods ( $p>0.05)$. Among the groups, the aqueous extract and saline presented less edema than the ethanolic extract, which showed significant differences from the other groups in both experimental periods $(p<0.05)$ (Figure 1$)$.

\section{Histological analysis}

The histological analysis was performed after 7 and 28 days, according ISO 10993-67. The analysis of all groups in relation to the experimental period showed a statistically significant difference between the ethanolic extract and the other groups for the 28-day period $(p<0.05)$ (Figure 2$)$.

At 7 days, moderate inflammatory infiltrate was present, probably due to surgical trauma (Figures 3-5). At 28 days, healing was in an advanced stage presenting lower levels of inflammation when compared with 7 days for the three groups (Figures
3-5). These differences were statistically significant $(p<0.05)$.

The ethanolic extract group showed persistency of inflammation with large amounts of inflammatory cells up to 28 days, with no statistically significant differences between 7 and 28 days ( $p>0.05$ ) (Figure 5).

\section{DISCUSSION}

Approximately $85 \%$ of the world's population depends on traditional medical treatments based on herbal medicines, and approximately $25 \%$ of the world's pharmaceutical medicines are derived from plants ${ }^{15}$.

Myracrodruon urundeuva, called Aroeira in Brazil, was chosen for this study because of its antibacterial properties demonstrated in previous studies ${ }^{8}$. The present study evaluated the inflammatory tissue response to aqueous and ethanolic Aroeira extracts. During the studied period, wound healing was in an advanced stage, presenting diminished levels of inflammation for aqueous and control group. However, the ethanolic extract group demonstrated persistency of inflammation until up to the $28^{\text {th }}$ day. This result may be due to some component released during the preparation of the extract rather than ethanol.

Although clinical studies ${ }^{10}$ revealed an absence of significant toxic effects of the plant elixir, Repetto, et al. ${ }^{16}$ (1997) showed that the ethanolic Aroeira extract can be considered toxic.

The edemogenic analysis demonstrated slightly reduction of edema by the aqueous Aroeira extracts in relation to the control group, while the ethanolic extract group showed significantly more edema.

The experimental periods for histological analysis were based in previous studies, which showed an unaltered tissue response after 30 days $^{6}$. The use of polyethylene tubes with a paper cone was based on Pullin and Carvalho ${ }^{14}$ (1984).

The histological analysis also showed a significantly worse result for the ethanolic extract in relation to persistency of inflammation up to 28 days. There were no signs of adequate wound healing when comparing to other groups. On the other hand, Natural Resources Conservative Service (USA $\left.{ }^{20}, 2012\right)$ used the same methodology and found better results with ethanolic Araçá extract.

In the present study, the aqueous extract group presented healing evolution similar to that of the saline group and at 28 days was slightly better despite not significant. The moderate inflammatory infiltrate observed at 7 days may be due to surgical trauma rather than a reaction to the extracts ${ }^{17}$. 


\section{CONCLUSION}

In conclusion, the biological response the Aroeira's aqueous extract is biocompatible and similar the response to saline. The ethanolic extract interfered with the wound healing maintaining the inflammation up to advanced periods.

\section{ACKNOWLEDGEMENTS}

This research is supported by Coordenação de Aperfeiçoamento de Pessoal de Nível Superior (CAPES).

Authors declare there are no financial/commercial conflicts of interest of this study.

\section{REFERENCES}

1- Almeida AC, Sobrinho EM, Pinho L, Silva PN, Martins ER, Duarte ER, et al. Toxicidade aguda dos extratos hidroalcoólicos das folhas de alecrim-pimenta, aroeira e barbatimão e do farelo da casca de pequi administrados por via intraperitoneal. Cienc Rural. 2010;40(1):200-3.

2- Bernabé PFE, Holland R, Paiva JG, Souza V, Nery MJ, Mello $W$. Behaviour of the subcutaneous connective tissue to the implantation of some materials employed in retrograde filling. Rev Fac Odontol Araçatuba. 1978;7(1):7-17.

3- Fédération Dentaire International. Commission of Dental Materials Instruments, Equipment and Therapeutics. Recommended standard practices for biological evaluation of dental materials. Int Dent J. 1980;30(2):140-88.

4- Gera M, Bisht NS, Rana AK. Market information system for sustainable management of medicinal plants. Indian Forester. 2003;129(1):102-8.

5- Goes AC, Rodrigues LV, Menezes DB, Grangeiro MP, Cavalcante AR. Histologic analysis of colonic anastomotic healing, in rats, under the action of $10 \%$ Aroeira-do-sertão (Myracrodruon urundeuva fr. all.) enema. Acta Cirurgica Brasileira. 2005;20:144-51.

6- Holland R, Souza V, Nery MJ, Faraco Júnior IM, Bernabé PF, Otoboni Filho JA, et al. Reaction of rat connective tissue to implanted dentin tube filled with a white mineral trioxide aggregate. Braz Dent J. 2002;13(1):23-6.

7- International Organization for Standardization. ISO 10993-6: Biological evaluation of medical devices - Part 6: Tests for local effects after implantation. Geneva: ISO; 2007.

8- Landucci LF, Brandão EHS, Koga-Ito CY, Jardim Júnior EG, Jorge AOC. Efeitos de Coffea arabica sobre a aderência de Streptococcus mutans à superfície de vidro. Ciênc Odontol Bras. 2005;6(3):21-60.
9- Martins ER, Castro DM, Catellane DC, Dias JE. Plantas medicinais. Viçosa: Editora UFV; 2000.

10- Melo GS, Pimentel MLL, Bandeira MM, Viana GSB, Moraes MO, Bezerra FAF, et al. Toxicologia clínica e laboratorial do elixir de aroeira-do-sertão, Myracrodruon urundeuva allemão. In: Simpósio de Plantas Medicinais do Brasil, 15., 1998, Águas de Lindóia, Brasil. Anais, Águas de Lindóia, 1998.

11- Monteiro MV, Melo Leite AK, Bertini LM, Morais SM, Nunes Pinheiro DC. Topical anti-inflammatory, gastroprotective and antioxidant effects of the essential oil of Lippia sidoides Cham. leaves. J Ethnopharmacol. 2006;111:378-82.

12- Navarro DF, Santos EAT, Rocha JCF, Bremm LL, Jukoski M, Ribeiro PG, et al. Efeitos do digluconato de clorexidina, Plantago major e placebo sobre placa dental e gengivite: uma comparação clínica de eficácia de colutórios. Rev Bras PI Med. 1998;1:28-38. 13- Nobre-Junior HV, Oliveira RA, Maia FD, Nogueira MA, Moraes MO, Bandeira MA, et al. Neuroprotective effects of chalcones from Myracrodruon urundeuva on 6-Hydroxydopamine-Induced cytotoxicity in rat mesencephalic cells. Neurochem Res. 2009;34:1066-75.

14- Pullin AM, Carvalho ACP. Subcutaneous conjuctive tissue reaction to alcohol and/or local anesthetic solutions. A histological study in rats. Revista Gaúcha de Odontologia. 1984;32:287-95. 15- Rai LK, Prasad P, Sharma E. Conservation threats to some important medicinal plants of the Sikkin Himalaya. Biological Conservation. 2000;3:27-33.

16- Repetto M. Toxicologia experimental. In: Repetto M. Toxicologia fundamental. $3^{\text {rd }}$ ed. Madrid: Diaz de Santos; 1997. p. 291-300. 17- Torneck CD. Reaction of rat connective tissue to polyethylene tube implants. Oral Surg Oral Med Oral Pathol. 1967;24(5):674-83. 18- Tsuchiya H, Sato M, Iinuma M, Yokoyama J, Ohyama M, Tanaka $\mathrm{T}$, et al. Inhibition of growth of cariogenic bacteria in vitro by plant flavanones. Experientia. 1994;50(9):846-9.

19- Viana GS, Bandeira MA, Matos FJ. Analgesic and antiinflammatory effects of chalcones isolated from Myracrodruon urundeuva allemão. Phytomedicine. 2003;10:189-95.

20- United States. United States Departments of Agriculture. Natural Resources Consevative Service; c2012 [cited 2012 Sept. 10]. Available from: http://plant_materials.nrcs.usda.gov. 21- Viana GS, Bandeira MA, Moura LC, Souza-Filho MVP, Matos FJA, Ribeiro RA. Analgesic and antiinflammatory effects of the tannin fraction from Myracrodruon urundeuva Fr. All. Phytotherapy Research. 1997; 11:118-22.

22- Volpato GT, Damasceno DC, Calderon IMP, Rudge MVC. Revisão de plantas brasileiras com comprovado efeito hipoglicemiante no controle do Diabetes mellitus. Rev Bras Plantas Med. 2002;4(2):35-45.

23- World Health Organization. Regulatory situation of herbal medicines: a worldwide rewiew. Geneva: WHO; 1998. 